\title{
Pengaruh Pengendalian Internal, Kompetensi dan Locus Of Control Pada Kecenderungan Kecurangan Akuntansi
}

\author{
I Gede Beni Wirakusuma ${ }^{1}$ \\ Putu Ery Setiawan ${ }^{2}$ \\ ${ }^{1,2}$ Fakultas Ekonomi dan Bisnis Universitas Udayana (Unud), Bali, Indonesia \\ e-mail: beniwirakusuma@yahoo.com
}

\begin{abstract}
ABSTRAK
Penelitian ini bertujuan untuk mengetahui pengaruh pengendalian internal, komptetensi dan locus of control pada kecenderungan kecurangan akuntansi. Penelitian ini dilakukan di Dinas Pendapatan Daerah Kota dengan metode survey menggunakan kuesioner. Jumlah sampel yang dianalisis sebanyak 80 responden dengan menggunakan metode penentuan sampel purposive sampling. Teknik analisis data dalam penelitian ini menggunakan analisis regresi linear berganda.Berdasarkan hasil analisis yang dilakukan maka diperoleh kesimpulan bahwa hasil analisis data menunjukkan bahwa pengendalian internal dan komptensi berpengaruh negatif pada kecenderungan kecurangan akuntansi. Sedangkan locus of control berpengaruh positif pada kecenderungan kecurangan akuntansi.

Kata Kunci : Pengendalian Internal, Kompetensi, Locus Of Control, Kecenderungan Kecurangan Akuntansi
\end{abstract}

\begin{abstract}
This study aims to determine the effect of internal control, competence and locus of control on accounting fraud tendencies.This research was conducted in the Municipal Revenue Office with a survey method using a questionnaire. The number of samples analyzed was 80 respondents using a purposive sampling method. The data analysis technique in this study used multiple linear regression analysis.Based on the results of the analysis carried out, it can be concluded that the results of data analysis show that internal control and competence negatively affect the tendency of accounting fraud. Whereas locus of control has a positive effect on accounting fraud tendencies.
\end{abstract}

Key word: Internal Control, Competence, Locus Of Control, Accounting Fraud Trends

\section{PENDAHULUAN}

Reformasi yang terjadi di institusi pemerintah mulai ada sejak dikeluarkannya beberapa landasan hukum. Adapun bentuk pertanggungjawaban pemerintah pada masyarkat yaitu melalu laporan keuangan yang melaporkan segala aktivitas pengelolaan keuangan di institusi pemerintah. Manipulasi akuntansi mungkin dilakukan dalam praktik-praktik bisnis oleh perusahaan dan biasanya melibatkan pihak-pihak intern. Kecurangan akuntansi telah mendapat banyak perhatian publik sebagai dinamika yang menjadi pusat perhatian para pelaku bisnis di dunia. Kasus 
I Gede Beni Wirakusuma dan Putu Ery Setiawan. Pengaruh...

Kecenderungan Kecurangan Akuntansi (KKA) di Indonesia terjadi secara berulang-ulang. Korupsi merupakan tindakan pejabat publik, baik politisi maupun pegawai negeri, serta pihak lain yang terlibat dalam tindakan secara tidak wajar menyalahgunakan kepercayaan publik dan merupakan termasuk kecurangan. Kecurangan akuntansi dapat dikatakan sebagai tendensi korupsi dalam definisi dan terminologi karena keterlibatan beberapa unsur yang terdiri dari faktafakta menyesatkan, pelanggaran aturan atau penyalahgunaan kepercayaan, dan omisi fakta kritis. Pencegahan fraud di sektor publik dilakukan dengan mengeluarkan berbagai peraturan perundang-undangan yang menetapkan berbagai sanksi yang diharapkan dapat menangkal atau setidak-tidaknya dapat mengurangi tindakan kecurangan. Tindakan yang terjadi karena adanya peluang untuk salah saji dalam laporan keuangan dan salah saji yang timbul dari perlakuan tidak semestinya terhadap aset disebut kecenderungan kecurangan akuntansi (Norbarani, 2012). Faktor rasionalisasi dan tekanan merupakan karakteristik pelaku kecurangan akuntansi tidak dapat diobservasi karena mustahil untuk mengetahui apa yang dipikirkan oleh pelaku ketika melakukan kecurangan akuntansi (Dorminey, Flemming, Kranacher, \& Riley, 2010). Adapun faktor yang membedakannya adalah tindakan yang mendasari, apakah tindakan tersebut dilakukan secara disengaja atau tidak. Jika tindakan dilakukan secara sengaja, maka disebut kecurangan, Sedangkan dengan cara tidak sengaja maka disebut kekeliruan (Singleton \& Singleton, 2013). Kecurangan akuntansi menyangkut cara - cara yang dihasilkan oleh akal manusia yang dipilih oleh seseorang untuk mendapatkan keuntungan dari pihak lain dengan penyajian yang salah atau palsu 
(Abdul Wahid \& Zulkarnain, 2011). Kecurangan akuntansi mengacu pada kesalahan akuntansi yang dilakukan secara sengaja dengan tujuan menyesatkan pengguna laporan keuangan kecurangan akuntansi dapat terjadi dikarenakan beberapa kondisi yang menyebabkan hal tersebut terjadi hal ini disebut dengan segitiga kecurangan (fraud triangle) yaitu tekanan, kesempatan, dan sikap/rasionalisasi (Albrecht \& Zimbelman, 2012). Ditinjau dari teori atribusi, teori membahas penyebab - penyebab perilaku seseorang dan upaya untuk memahami peneyabab dibalik perilaku seseorang. Perilaku kecurangan terjadi karena adanya faktor internal dan eksternal. Seseorang mungkin merasa dapat tekanan untuk melakukan kecurangan karena adanya kebutuhan atau masalah finansial. Kesempatan merupakan peluang yang menyebabkan pelaku secara leluasa menjalankan aksinya yang disebabkan oleh pengendalian internal yang lemah. (Andrawina \& Kurniawati, 2012). Kecurangan merupakan penyimpangan dan perbuatan hokum secara sengaja untuk keuntungan pribadi atau kelompok (Pedneault, Silverstone, Rudewicz, \& Sheetz, 2012).

Pengendalian internal yang baik mampu membuat perusahaan siap dalam menghadapi perubahan ekonomi yang cepat untuk kemajuan yang akan datang. (Hermiyetti \& Manik, 2010). Sebaliknya pengendalian internal yang lemah memungkinkan terjadinya kesalahan dan kecurangan semakin besar (Putri, 2014). Kefektifan pengendalian internal mempunyai pengaruh yang besar dalam upaya pencegahan kecenderungan kecurangan akuntansi, dengan adanya pengendalian internal maka pengecekan akan terjadi secara otomatis terhadap pekerjaan seseorang oleh orang lain (Zainal, 2013). Pengendalian internal sangat penting 
I Gede Beni Wirakusuma dan Putu Ery Setiawan. Pengaruh...

dalam organisasi untuk meminimalisir terjadinya kecurangan pengendalian internal yang dilakukan secara efektif akan menutup peluang terjadinya kecenderungan untuk berlaku curang dalam akuntansi (Adelin \& Fauzihardani, 2013). Instansi Pemerintah penting untuk menerapkan Sistem Pengendalian Internal untuk mencegah terjadinya tindak kecurangan yang dapat merugikan instansi.Penerapan Sistem Pengendalian Intern secara baik yang diharapkan dapat memotivasi dan meningkatkan kepuasan kerja karyawan. Dengan Adanya pengendalian internal yang efektif didalam suatu instansi, maka akan memungkinkan terjadinya pengecekan silang terhadap pekerjaan seseorang oleh orang lain. Hal ini menurunkan peluang terjadinya kecurangan dan akan menghindarkan terjadinya tindakan-tindakan penyimpangan yang dapat merugikan perusahaan.

Kompetensi adalah karateristik yang mendasari seseorang berkaitan dengan efektivitas kinerja individu dalam pekerjaannya atau kateristik dasar individu yang memiliki hubungan kausal atau sebagai sebab akibat dengan kriteria yang dijadikan acuan, efektif atau berkinerja prima atau superior di tempat kerja atau pada situasi tertentu. Kompetensi merupakan perilaku atau perbuatan seseorang meliputi kemampuan umum, ketrampilan dan pengetahuan tentang kebijaksanaan aturan dan pedoman pelaksanaan tugas (Sawyer, 2005). Sehingga dengan kompetensi yang dimiliki oleh pegawai yang sesuai dalam suatu perusahaan dapat menciptakan keefektifan kerja. Pegawai yang berkompetensi dan memiliki kemampuan kerja yang baik akan mendukung pencapaian tujuan perusahaan (Popoola, Che-Ahmad, \& Samsudin, 2014). Kompetensi yang rendah 
juga akan mengakibatkan kegagalan dalam audit karena auditor akan kesulitan dalam menemukan temuan - temuan yang berkenaan dengan terjadinya penyimpangan (Johnson-Rokosu, 2015). Kompetensi adalah bagian kepribadan yang mendalam dan melekat kepada seseorang serta perilaku yang dapat diprediksi pada berbagai keadaan dan tugas pekerjaan. Kompetensi merupakan sikap yang harus dimiliki auditor yang diperoleh dengan menggunakan keahlian dan pelatihan teknis yang cukup sebagai auditor.

Locus Of Control dapat dikatakan sebagai cara pandang seseorang terhadap suatu peristiwa apakah dia dapat atau tidak dalam mengendalikan peristiwa yang terjadi padanya (Lee, 2013). Untuk menjadi seorang akuntan dalam melaksanakan tugas profesionalnya juga dipengaruhi oleh locus of control yang berkaitan dengan adanya takdir, kepercayaan diri dan usaha atau kerja keras dari akuntan itu sendiri atau sering dikatakan sebagai locus of control eksternal (Rubin, 2009). locus of control eksternal adalah adalah suatu kondisi dimana individu-individu meyakini bahwa apa yang terjadi pada diri mereka dikendalikan oleh kekuatan dari luar, seperti nasib dan kesempatan baik. Manajemen yang menilai kontrol eksternal merasa bahwa hasil yang mereka capai itu di luar kontrol mereka sendiri, mereka merasa bahwa kekuatan-kekuatan eksternal seperti keberuntungan atau tingkat kesulitan terhadap tugas yang dijalankan, itu lebih menentukan hasil kerja mereka. Locus Of Control eksternal juga dapat dikatakan sebagai situasi dimana individu-individu dengan lokus kendali eksternal merasa tidak mampu dalam mendapatkan dukungan kekuatan yang dibutuhkannya untuk bertahan dalam suatu organisasi, maka mereka akan memiliki potensi untuk 
I Gede Beni Wirakusuma dan Putu Ery Setiawan. Pengaruh...

mencoba memanipulasi rekan atau objek lainnya sebagai kebutuhan pertahanan mereka.

Penelitian ini dilakukan di Dinas Pendapatan Kota Denpasar karena merupakan salah satu unit kerja di lingkungan Pemerintah Kota Denpasar yang mempunyai tugas pokok dan fungsi mengkoordinasikan target penerimaan Pendapatan Asli Daerah dan dana perimbangan yang berasal dari dana bagi hasil pajak dan bukan pajak serta merealisasikannya bersama-sama kepada unit satuan kerja yang terkait sesuai dengan tahapan yang telah ditetapkan agar dapat dipergunakan untuk membiayai rencana kegiatan yang sudah ditetapkan. Dinas Pendapatan merupakan unsur pelaksana pemerintah daerah di bidang pendapatan daerah. Oleh karena itu, Kota Denpasar dituntut dapat memiliki kemandirian dalam pengelolaan sumber-sumber keuangan daerah serta peningkatan sumber daya manusianya. Dengan tujuan untuk mengetahui pengaruh pengendalian internal, kompetensi dan locus of control pada kecenderungan kecurangan akuntansi. Dengan adanya penelitian ini dapat memberikan masukan bagi manajemen untuk menerapkan peraturan dan melakukan evaluasi kinerja pegawai secara intensif. Landasan teori yang digunakan dalam penelitian ini yaitu Teori Atribusi dan Fraud Triangle Theory. Menurut (Robbins \& Judge, 2009) teori atribusi ini menjelaskan bahwa ketika individu mengamati perilaku seseorang, individu tersebut berupaya menentukan apakah perilaku tersebut disebabkan secara internal atau eksternal. Teori ini juga menjelaskan bahwa terdapat perilaku yang berhubungan dengan sikap dan karakteristik individu (Schuchter \& Levi, 2016). Teori atribusi mempelajari proses bagaimana seseorang 
menginterpretasikan suatu peristiwa, alasan, atau sebab perilakunya yang dipengaruhi oleh kekuatan internal dan eksternal yang akan mencerminkan perilaku kepemimpinan seseorang tersebut. Kecurangan akuntansi dapat terjadi apabila ada peluang untuk melakukan hal tersebut dan peluang tersebut dapat dikurangi dengan sistem pengendalian internal yang baik. Pengendalian internal yang baik dapat mengurangi atau bahkan menutup peluang untuk melakukan kecurangan akuntansi. Teori atribusi menjelaskan tindakan seorang pemimpin maupun orang yang diberikan wewenang disebabkan oleh atribut penyebab. Tindakan yang tidak etis dan tindakan curang dapat dipengaruhi oleh adanya sistem pengendalian internal dan monitoring oleh atasan.

Teori selanjutnya yaitu Fraud Triagle Theory menurut (Tuanakotta, 2010) menyatakan bahwa korupsi disebabkan karena 3 faktor yaitu tekanan (pressure), peluang (opportunity) dan rasionalisasi (rasionalitation). individu dengan tingkat integritas tinggi dan tekanan (kebutuhan) serta kesempatan terbatas untuk melakukan kecurangan cenderung bersikap jujur, sebaliknya individu yang integritas pribadinya kurang, ketika ditempatkan dalam situasi tekanan kebutuhan meningkat dan diberikan kesempatan cenderung melakukan kecurangan asalkan kebutuhannya terpenuhi. Rasionalisasi menjadi elemen penting dalam terjadinya kecurangan, dimana pelaku mencari pembenaran atas perbuatannya. Rasionalisasi merupakan bagian fraud triangle yang paling sulit untuk diukur. Tekanan atau (pressure) yaitu intensif yang mendorong orang untuk melakukan kecurangan karena tuntutan gaya hidup, ketidakberdayaan dalam soal keuangan, perilaku gambling, mencoba - coba untuk mengalahkan sistem dan ketidakpuasan kerja. 
I Gede Beni Wirakusuma dan Putu Ery Setiawan. Pengaruh...

Kesempatan (opportunity) yaitu peluang yang menyebabkan pelaku dapat secara leluasa menjalankan aksinya yang disebabkan oleh pengendalian internal yang lemah. Sikap (Rasionalisasi) yaitu karakter atau serangkaian nilai - nilai etis yang membenarkan pelaku untuk melakukan tindakan kecurangan dengan mencari pembenaran atas perbuatannya. Kecurangan akuntansi sering terjadi karena adanya kesempatan yang terbuka lebar dalam organisasi, semakin lebar suatu kesempatan tercipta maka semakin besar pula kemungkinan terjadi kecurangan akuntansi (Donelson, Ege, \& McInnis, 2017).

Menurut Dewi (2014) menyatakan bahwa kecenderungan individu melakukan kecurangan akuntansi dalam kondisi tidak terdapat pengendalian internal. Pengendalian internal yang efektif dalam suatu instansi maka akan memungkinkan terjadinya pengecekan silang terhadap pekerjaan seseorang oleh orang lain (Coram, Ferguson, \& Moroney, 2008). Teori itu juga didukung oleh penelitian Setiawan (2015) yang menyatakan bahwa sistem pengendalian intern berpengaruh signifikan negatif terhadap kecurangan. Semakin baik sistem pengendalian internal suatu perusahaan maka semakin berkurang tingkat kecurangan akuntansi yang terjadi. Kecurangan akuntansi sering terjadi karena adanya kesempatan yang terbuka lebar dalam organisasi. Semakin lebar suatu kesempatan tercipta, maka semakin besar pula kemungkinan terjadi kecurangan akuntansi. Untuk itu salah satu cara menanggulanginya adalah dengan menciptakan sistem pengendalian internal yang baik dalam organisasi tersebut. Dengan sistem pengendalian internal yang efektif dapat mengurangi bahkan menutupi kesempatan untuk terjadinya kecurangan akuntansi. 
$\mathrm{H}_{1}$ : Pengendalian internal berpengaruh negatif pada kecenderungan kecurangan akuntansi.

Menurut (Khine et al., 2005) kompetensi adalah sebuah hubungan cara cara setiap auditor memanfaatkan pengetahuan, keahlian dan pengalaman. Auditor yang tidak kompeten tidak akan mampu membantu manajemen dalam memecahkan masalah yang memiliki resiko. Dapat dikatakan semakin baik tingkat kompetensi seseorang maka tindak kecurangan akuntansi berkurang. $\mathrm{H}_{2}$ : Kompetensi berpengaruh negatif pada kecenderungan kecurangan akuntansi.

Menurut (Robbins \& Judge, 2009) Locus of Control adalah sejauh mana orang yakin bahwa mereka menguasai nasib mereka sendiri. Seseorang dengan Locus of Control eksternal meyakini bahwa kejadian dalam hidupnya dipenuhi oleh takdir dan keberuntungan serta kekuasaan, sehingga kejadian yang terjadi pada dirinya adalah diluar dari pengendalian. Semakin tinggi tingkat locus of control eksternal maka semakin tinggi tingkat kecenderungan akuntansi. Locus of control merupakan konsep yang beranggapan bahwa suatu kepercayaan seseorang terkait akan perilaku serta konsekuensi yang akan dihadapinya.

Locus of control adalah konsep yang menjelaskan tentang persepsi seseorang terhadap siapa yang menetukan nasibnya. Eksternal locus of control adalah cara pandang dimana segala hasil yang didapat, baik atau buruk berada di luar kontrol diri mereka tetapi karena faktor luar seperti keberuntungan, kesempatan, dan takdir. Individu yang termasuk dalam kategori ini meletakkan tanggung jawab di luar kendalinya.

$\mathrm{H}_{3}$ : Locus Of Control berpengaruh positif pada kecenderungan kecurangan akuntansi. 
I Gede Beni Wirakusuma dan Putu Ery Setiawan. Pengaruh...

\section{METODE PENELITIAN}

Desain penelitian yang digunakan pada penelitian ini adalah pendekatan kuantitatif yang berbentuk asosiatif yaitu penelitian ini dilakukan untuk mengetahui pengaruh pengendalian internal, komptensi, dan locus of control pada kecenderungan kecurangan akuntansi.

Penelitian ini dilaksanakan di Dinas Pendapatan Daerah Kota Denpasar yang beralamatkan di JL. Tantular no. 12, Dangin Puri Kelod, Denpasar Timur. Objek dalam penelitian ini adalah pegawai Dinas Pendapatan Daerah Kota Denpasar.

Variabel - variabel yang digunakan dalam penelitian ini dikelompokan menjadi 2 yaitu variabel bebas dan variabel terikat. Variabel bebas atau Independen merupakan variabel yang mempengaruhi variabel dependen atau terikat. Variabel bebas dalam penelitian ini adalah yang pertama pengendalian internal (X1), kedua kompetensi (X2) dan yang ketiga locus of control (X3). Variabel terikat atau Dependen variabel yang dipengaruhi atau yang menjadi akibat karena adanya variabel bebas. Variabel terikat pada penelitian ini adalah kecenderungan akuntansi (Y).

Variabel independen pertama dalam penelitian ini yaitu pengendalian internal. Pengendalian internal diartikan sebagai control dalam suatu organisasi dengan tujuan mengawasi dan mengarahkan sumber daya organisasi sehingga dapat membantu organisasi dalam mencapai tujuannya. Pengendalian internal meliputi lima kategori yang dirancang dan diimplementasikan oleh manajemen untuk memberikan jaminan bahwa sasaran hasil pengendalian manajemen akan 
terpenuhi. Pengendalian internal menurut (Shintadevi, 2015) diukur dengan menggunakan 5 indikator yaitu lingkungan pengendalian, penilaian resiko, aktivitas pengendalian, informasi dan komunikasi dan pemantauan.

Variabel independen yang kedua pada penelitian ini yaitu kompetensi, menurut peraturan pemerintah no 1 tahun 2000, kompetensi adalah kemampuan dan karakteristik yang dimiliki oleh seorang pns berupa pengetahuan serta sikap perilaku yang diperlukan dalam tugas dan jabatan. Adapun indikator penelitian menurut (Yendrawati, 2013) meliputi 5 yaitu memiliki pengetahuan, kompetensi lain dalam melaksanakan tanggung jawab, keahlian dan kemampuan yang menyangkut objek yang diperiksa, keahlian yang menyangkut teknik dan keahlian dalam menyampaikan hasil pemeriksaan.

Variabel independen ketiga pada penelitian ini yaitu Locus of Control, pada penelitian ini yang digunakan adalah locus of control eksternal yaitu suatu kondisi dimana individu yakin bahwa apa yang terjadi pada diri mereka dikendalikan oleh kekutan dari luar seperti nasib dan kesempatan baik. Manajemen yang menilai kontrol eksternal merasa bahwa hasil yang mereka capai itu di luar kontrol mereka sendiri, mereka merasa bahwa kekuatan-kekuatan eksternal seperti keberuntungan atau tingkat kesulitan terhadap tugas yang dijalankan, itu lebih menentukan hasil kerja mereka. Adapun indikator locus of control eksternal terdiri dari 3 aspek yaitu nasib, social ekonomi, dan pengaruh orang lain (Respati, 2011)

Variabel dependen pada penelitian ini adalah kecenderungan kecurangan akuntansi. Kecenderungan kecurangan akuntansi merupakan tindakan sengaja 
I Gede Beni Wirakusuma dan Putu Ery Setiawan. Pengaruh...

melakukan sesuatu hal yang merugikan untuk memperoleh suatu keuntungan dengan memanipulasi sehingga melaporkan laporan keuangan tidak sesuai dengan keadaan yang sebenarnya. Kecenderungan Kecurangan Akuntansi (KKA) adalah keinginan untuk melakukan segala sesuatu untuk memperoleh keuntungan dengan cara yang tidak jujur seperti menutupi kebenaran, penipuan, manipulasi, kelicikan atau mengelabui yang dapat berupa salah saji atas laporan keuangan, korupsi dan penyalahgunaan aset. Adapun indikator pengukuran kecenderungan kecurangan akuntansi yang dikembangkan menurut (Shintadevi, 2015) yaitu kecenderungan untuk melakukan manipulasi, pemalsuan, atau perubahan catatan akuntansi atas dokumen pendukungnya, kecenderungan untuk melakukan penyajian yang salah atau penghilangan peristiwa, kecenderungan untuk melakukan salah dalam penerapan prinsip akuntansi secara sengaja, kecenderungan untuk melakukan penyajian laporan keuangan yang salah akibat penyalahgunaan terhadap aktiva, dan kecenderungan untuk melakukan penyajian laporan keuangan yang salah akibat perlakuan yang tidak semestinya terhadap ajtiva disertai dengan catatan atau dokumen palsu menyangkut satu atau lebih individu.

Populasi merupakan wilayah generalisasi yang terdiri atas objek maupun subjek yang mempunyai kualitas dan karakteristik tertentu yang ditetapkan oleh peneliti untuk dipelajari dan ditarik kesimpulannya (Sugiyono, 2014). Pada penelitian ini populasinya adalah pegawai Dinas Pendapatan Daerah Kota Denpasar yang berjumlah 90 orang.

Sampel merupakan bagian dari jumlah yang dimiliki dari populasi tersebut. Penelitian ini menggunakan teknik penentuan sampel nonprobability 
sampling dengan purposive sampling. Purposive Sampling adalah teknik penentuan sampel dengan pertimbangan tertentu (Sugiyono, 2011). Pada penelitian ini yang dijadikan sampel adalah kepala bagian keuangan dan staf bagian keuangan di Dinas Pendapatan Daerah Kota Denpasar.

Metode pengumpulan data yang digunakan pada penelitian ini adalah metode survei dengan menggunakan kuesioner, yaitu dengan cara memberikan serangkaian pertanyaan atau pernyataan tertulis kepada responden untuk dijawab. Adapun jenis data yang digunakan pada penelitian ini adalah data kuantitatif yaitu data yang berbentuk angka, atau data yang berbentuk kualitatif yang diangkakan. Data kuantitatif dalam penelitian ini berupa hasil pengisian kuesioner. Dan sumber data yang digunakan dalam penelitian ini adalah data primer, yaitu sumber data yang langsung memberikan data kepada pengumpul data. Data primer dalam penelitian ini adalah jawaban responden terhadap kuesioner.

Teknik analisis data yang digunakan dalam penelitian ini adalah teknik analisis regresi linear berganda, yaitu analisis ini digunakan untuk mengetahui arah dan besarnya pengaruh dari variabel bebas yang akan diteliti yaitu untuk mengukur pengendalian internal, kompetensi, dan locus of control pada kecenderungan kecurangan akuntansi. Selain itu, penelitian ini juga perlu dilakukan uji instrument penelitian yang meliputi uji validitas dan reliabilitas, uji asumsi klasik yang meliputi uji normalitas, uji heterokedastisitas, dan uji multikolinearitas, serta uji koefisien determinasi, uji signifikansi $F$ dan uji hipotesis (uji t). 


\section{HASIL DAN PEMBAHASAN}

Data yang diperoleh pada penelitian ini dari hasil penyebaran kuesioner yang telah disebarkan kepada responden penelitian yang berjumlah 90 orang, dengan tingkat pengembalian sebanyak 80 orang, kuesioner yang tidak kembali adalah kuesioner yang disebar di Dinas Pendapatan Daerah Kota Denpasar. Adapun karakteristik responden yang diteliti pada penelitian ini meliputi jenis kelamin, umur responden, pendidikan terakhir, serta masa kerja responden. Berdasarkan tabel 1, dapat dilihat hasil statistik deskriptif. Statistik deskriptif dalam penelitian ini memberikan informasi mengenai kecenderungan responden yang mengisi kuesioner pada indikator masing-masing variabel yang terdapat pada pernyataan dalam kuesioner penelitian. Pengukuran kecenderungan responden pada indikator masing-masing variabel diukur menggunakan nilai ratarata (mean).

Tabel 1.

Hasil Analisis Statistik Deskriptif

\begin{tabular}{lcccc}
\hline \multicolumn{1}{c}{ Variabel } & $\begin{array}{c}\text { Nilai } \\
\text { Minimum }\end{array}$ & $\begin{array}{c}\text { Nilai } \\
\text { Maksimum }\end{array}$ & Mean & $\begin{array}{c}\text { Standar } \\
\text { Deviasi }\end{array}$ \\
\hline $\begin{array}{l}\text { Pengendalian Internal } \\
\text { (X1) }\end{array}$ & 51 & 96 & 80,69 & 11,771 \\
Kompetensi (X2) & 27 & 52 & 43,43 & 6,336 \\
Locus Of Control (X3) & 34 & 69 & 54,10 & 10,765 \\
Kecenderungan & 15 & 63 & 33,43 & 12,743 \\
Kecurangan Akuntansi ( & & & & \\
Y) & & & & \\
ber: Data diolah, 2018 & & & &
\end{tabular}

Berdasarkan tabel di atas dideskripsikan bahwa jumlah responden (N) adalah 80. Dari 80 responden ini variabel independen pengendalian internal memiliki nilai minimum 51 nilai maksimum 96, nilai mean 80,69 dengan standar deviasi 11,771. Kompetensi memiliki nilai minimum 27, nilai maksimum 52, nilai mean 43,43 dengan standar deviasi 6,336. Locus Of Control memiliki nilai 
minimum 34 , nilai maksimum 69 , nilai mean 54,10 dengan standar deviasi 10,765. Sedangkan pada variabel dependen yaitu kecenderungan kecurangan akuntansi memiliki nilai minimum 15 , nilai maksimum 63 , nilai mean 33,43 dengan standar deviasi 12,743.

Uji validitas digunakan untuk mengukur valid atau sah tidaknya suatu kuesioner. Penyusunan ini dilakukan untuk menguji apakah instrumen penelitian yang digunakan dalam penelitian ini tepat. Suatu instrumen dikatakan valid jika koefisien korelasi (r) hitung yang bernilai lebih besar dari $r$ tabel, yaitu diatas 0,3 $(\mathrm{r}>0,3)$.

Hasil uji validitas menunjukkan bahwa seluruh variabel memiliki nilai koefisien korelasi dengan skor total seluruh item pernyataan lebih besar dari 0,30 . Hal ini menunjukkan bahwa butir-butir pernyataan dalam instrumen penelitian tersebut valid.

Uji reliabilitas menggunakan teknik cronbach's alpha. Jika hasil dari cronbach's alphadiatas 0,60 maka instrumen yang digunakan dikatakan reliabel. Hasil uji reliabilitas dapat dilihat pada Tabel 2 berikut.

Tabel 2.

Hasil Uji Reliabilitas

\begin{tabular}{clcc}
\hline No & \multicolumn{1}{c}{ Variabel } & $\begin{array}{c}\text { Cronbach's } \\
\text { Alpha }\end{array}$ & $\begin{array}{c}\text { Keterang } \\
\text { an }\end{array}$ \\
\hline 1 & Pengendalian Internal $\left(\mathrm{X}_{1}\right)$ & 0,968 & Reliabel \\
2 & Kompetensi $\left(\mathrm{X}_{2}\right)$ & 0,953 & Reliabel \\
3 & Locus Of Control $\left(\mathrm{X}_{3}\right)$ & 0,964 & Reliabel \\
4 & KecenderunganKecurangan & 0,962 & Reliabel \\
& Akuntansi (Y) & & \\
\hline
\end{tabular}

Sumber : Data diolah, 2018

Hasil uji reliabilitas yang disajikan dalam Tabel 2 menunjukkan bahwa seluruh instrumen penelitian yaitu memiliki koefisien Cronbach's Alpha lebih 
dari 0,60. Hal ini menunjukkan bahwa semua instrumen reliabel sehingga dapat digunakan untuk melakukan penelitian.

Sebelum analisis data dilakukan data harus memenuhi syarat uji asumsi klasik. Yang pertama uji normalitas data dapat dilakukan dengan menggunakan One Sample Kolmogorov Smirnov yaitu dengan ketentuan apabila nilai signifikansi diatas 0,05 maka data terdistribusi normal. Pada tabel 3 berikut, menunjukan bahwa nilai signifikansi sebesar $0,160>0,05$, maka dapat disimpulkan bahwa variabel pengendalian internal, kompetensi dan locus of control pada kecenderungan kecurangan akuntansi berdistribusi secara normal.

Tabel 3.

Hasil Uji Asumsi Klasik

\begin{tabular}{|c|c|c|c|c|c|}
\hline \multirow{2}{*}{ Ket. } & \multicolumn{2}{|c|}{ Uji Normalitas } & \multicolumn{2}{|c|}{ Uji Multikolinearitas } & \multirow{2}{*}{$\begin{array}{c}\begin{array}{c}\text { Uji Heteroske } \\
\text { dastisitas }\end{array} \\
\text { Sig. }\end{array}$} \\
\hline & $\begin{array}{l}\text { Kolmogorov- } \\
\text { Smirnov }\end{array}$ & Sig. & Tolerance & VIF & \\
\hline PI & & & 0,315 & 3,173 & 0,976 \\
\hline Kompetensi & 1,124 & 0,160 & 0,342 & 2,927 & 0,216 \\
\hline $\begin{array}{l}\text { Locus Of } \\
\text { Control }\end{array}$ & & & 0,709 & 1,410 & 0,550 \\
\hline
\end{tabular}

Hasil Uji heteroskedastisitas bertujuan untuk menguji apakah dalam model regresi terjadi ketidaksamaan varians dari residual satu pengamatan ke pengamatan yang lain. Jika nilai signifikansinya berada diatas 0,05 maka model regresi ini dapat dikatakan bebas dari masalah heteroskedastisitas pada Tabel 3 memperlihatkan tingkat signifikansi tiap variabel bebas $>0,05$ sehingga dapat disimpulkan model regresi terbebas dari heteroskedastisitas.

Hasil uji multikolinearitas pada tabel 3 menunjukan variabel bebas pada model regresi tidak adanya korelasi dilihat dari nilai tolerance dan Varianc 
Inflation Factor (VIF), dengan kriteria sebagai berikut: 1) jika nilai VIF < 10 dan tolerance $>0,1$ maka variabel dapat dikatakan bebas dari gejala multikolonieritas; 2) jika nilai VIF $>10$ dan tolerance $<0,1$ maka terdapat gejala multikolonieritas Hasil uji multikolinearitas pada Tabel 3 diatas menunjukkan bahwa nilai tolerance variabel pengendalian internal sebesar $0,315>0,1$ dan nilai VIF sebesar 3,173 < 10, nilai tolerance variabel kompetensi sebesar $0,342>0,1$ dan nilai VIF sebesar $2,927<10$, nilai tolerance variabel locus of control sebesar $0,709>0,1$ dan nilai VIF sebesar $1,410<10$ jadi dapat disimpulkan bahwa data penelitian terbebas dari multikolinearitas.

Analisis regresi linear berganda merupakan analisis yang digunakan untuk mengetahui pengaruh pengendalian internal, kompetensi dan locus of control pada kecenderungan kecurangan akuntansi. Hasil dari analisis tersebut dapat dilihat pada Tabel 4 sebagai berikut:

Tabel 4.

Hasil Analisis Regresi Linear Berganda

\begin{tabular}{|c|c|c|c|c|c|}
\hline \multirow{2}{*}{ Variabel } & & \multicolumn{2}{|c|}{ Koefisien Regresi } & \multirow{2}{*}{$\mathbf{T}$} & \multirow{2}{*}{ Sig } \\
\hline & & $\mathbf{B}$ & Std. error & & \\
\hline (constant) & & 6,178 & 0,797 & 7,753 & 0,000 \\
\hline Pengendalian Internal & & $-0,644$ & 0,189 & $-3,414$ & 0,001 \\
\hline Kompetensi & & $-0,499$ & 0,185 & $-2,695$ & 0,009 \\
\hline Locus Of Control & & 0,202 & 0,096 & 2,102 & 0,039 \\
\hline Dependen variable & : Kecurangan & & & & \\
\hline F Statistik & $: \quad 45,668$ & & & & \\
\hline Sig F & $: \quad 0,000$ & & & & \\
\hline $\mathrm{R}^{2}$ & $: \quad 0,077$ & & & & \\
\hline Adjusted $\mathrm{R}^{2}$ & $: 0,040$ & & & & \\
\hline
\end{tabular}

Berdasarkan hasil analisis regresi linear berganda seperti yang disajikan pada

Tabel 4, maka diperoleh persamaan regresi linear berganda sebagai berikut:

$$
Y=6,178-0,644 X_{1}-0,499 X_{2}+0,202 X_{3}
$$


I Gede Beni Wirakusuma dan Putu Ery Setiawan. Pengaruh...

Konstanta sebesar 6,178 menyatakan bahwa apabila tidak terdapat pengaruh dari pengendalian internal, kompetensi dan locus of control maka variabel kecenderungan kecurangan akuntansi (Y) pada pegawai Dinas Pendapatan Daerah Kota Denpasar bernilai sebesar 6,178. Koefisien regresi variabel pengendalian internal $\left(\mathrm{X}_{1}\right)-0,644$. Hal ini berarti bahwa apabila variabel pengendalian internal $\left(\mathrm{X}_{1}\right)$ meningkat, maka akan mengakibatkan penurunan pada kecenderungan kecurangan akuntansi, dengan asumsi variabel bebas lainnya dianggap konstan. Koefisien regresi variabel kompetensi $\left(\mathrm{X}_{2}\right)-0,499$. Hal ini berarti bahwa apabila variabel kompetensi $\left(\mathrm{X}_{2}\right)$ meningkat, maka akan mengakibatkan penurunan pada kecenderungan kecurangan akuntansi, dengan asumsi variabel bebas lainnya dianggap konstan. Koefisien regresi variabel locus of control $\left(\mathrm{X}_{3}\right)$ 0,209. Hal ini berarti bahwa apabila variabel locus of control $\left(\mathrm{X}_{3}\right)$ meningkat, maka akan mengakibatkan peningkatan pada kecenderungan kecurangan akuntansi, dengan asumsi variabel bebas lainnya dianggap konstan.

Koefisien determinasi $\left(\mathrm{R}^{2}\right)$ bertujuan untuk mengukur seberapa jauh kemampuan model dalam menerangkan variasi variabel dependen. Besarnya nilai koefisien determinasi ditunjukkan dengan nilai Adjusted $R^{2}$ adalah sebesar 0,629. Artinya bahwa $62,9 \%$ variasi besarnya kecenderungan kecurangan akuntansi dapat dijelaskan oleh pengendalian internal, kompetensi dan locus of control. Sedangkan sisanya sebesar $37,1 \%$ dipengaruhi oleh variabel-variabel lain diluar model penelitian.

Sebelum dilakukan pengujian hipotesis, satu hal yang perlu diperhatikan adalah kelayakan model penelitian yang dilakukan dengan uji $\mathrm{F}$ untuk mengetahui 
apakah semua variabel independen yang dimasukkan dalam model mempunyai pengaruh secara bersama-sama pada variabel dependen. Jika nilai sig $\mathrm{F}<\alpha=0,05$ berarti variabel independen memengaruhi variabel dependen. Variabel independen layak digunakan untuk memprediksi variabel dependen, sehingga pembuktian hipotesis dapat dilanjutkan.

Hasil uji $\mathrm{F}$ ditunjukkan pada Tabel 5 menunjukkan nilai signifikansi uji $\mathrm{F}$ yaitu sebesar 0,000 yaitu lebih kecil dari 0,05. Hasil ini memberikan makna bahwa variabel bebas berpengaruh secara bersama-sama terhadap variabel terikat. Artinya ketiga variabel independen mampu memprediksi atau menjelaskan kecenderungan kecurangan akuntansi di Dinas Pendapatan Daerah Kota Denpasar.

Tabel 5.

Hasil Uji F

\begin{tabular}{cccccc}
\hline Model & $\begin{array}{c}\text { Sum of } \\
\text { Squares }\end{array}$ & Df & $\begin{array}{c}\text { Mean } \\
\text { Square }\end{array}$ & F & Sig \\
\hline Regression & 42,119 & 3 & 14,040 & 45,668 & $0,000^{\mathrm{a}}$ \\
Residual & 23,365 & 76 & 0,307 & & \\
Total & 65,484 & 79 & & & \\
\hline Sumber $:$ Data diolah, 2018 & & &
\end{tabular}

Uji t digunakan untuk mengetahui pengaruh masing-masing variabel independen terhadap variabel dependen (Ghozali, 2012:178). Kriteria penilaian dilakukan dengan melihat hasil regresi dengan program SPSS, yaitu membandingkan tingkat signifikansi masing-masing variabel bebas dengan $\alpha=$ 0,05. Apabila tingkat signifikansi $\mathrm{t} \leq \alpha=0,05$, maka $\mathrm{H}_{1}$ diterima dan $\mathrm{H}_{0}$ ditolak. Namun bila tingkat signifikansi $\mathrm{t}>\alpha=0,05$, maka $\mathrm{H}_{1}$ ditolak dan $\mathrm{H}_{0}$ diterima.

Hasil pengujian nilai t hitung pada variabel pengendalian internal adalah sebesar - 3,414 dengan tingkat signifikansi 0,001. Dengan menggunakan batas signifikansi 0,05 maka signifikansi tersebut dibawah taraf 5 persen yang berarti 
I Gede Beni Wirakusuma dan Putu Ery Setiawan. Pengaruh...

Ho ditolak dan $\mathrm{H}_{1}$ diterima. Variabel pengendalian internal berpengaruh negatif pada kecenderungan kecurangan akuntansi. Hal ini menunjukkan bahwa semakin baik pengendalian internal dalam Dinas Pendapatan Daerah Kota Denpasar, menyebabkan tingkat kecenderungan kecurangan akuntansi menurun. Apabila pengendalian internal buruk, menyebabkan tingkat kecenderungan kecurangan akuntansi meningkat. Jika ada pengawasan dan evaluasi atas aktivitas-aktivitas operasional secara terus-menerus dalam instansi, akan dapat membantu dalam mengatasi tindakan kecurangan. Hasil ini mendukung hipotesis pertama $\left(\mathrm{H}_{1}\right)$ yang menyatakan bahwa pengendalian internal berpengaruh negatif pada kecenderungan kecurangan akuntansi.

Nilai t hitung pada variabel kompetensi adalah sebesar -2,695 dengan tingkat signifikansi 0,009. Dengan menggunakan batas signifikansi 0,05 maka signifikansi tersebut dibawah taraf 5 persen yang berarti Ho ditolak dan $\mathrm{H}_{2}$ diterima. Variabel kompetensi berpengaruh negatif pada kecenderungan kecurangan akuntansi. Hal ini menunjukkan bahwa semakin tinggi kompetensi seseorang menyebabkan semakin rendah tindakan kecenderungan kecurangan akuntansi. Jika seseorang memiliki komptensi yang rendah akan mengakibatkan kegagalan dalam audit karena auditor akan kesulitan dalam menemukan temuan temuan yang berkenaan dengan terjadinya penyimpangan atau kecurangan akuntansi.

Nilai t hitung pada variabel locus of control adalah sebesar 2,102 dengan tingkat signifikansi 0,039. Dengan menggunakan batas signifikansi 0,05 maka signifikansi tersebut dibawah taraf 5 persen yang berarti Ho ditolak dan $\mathrm{H}_{3}$ 
diterima.Variabel locus of control eksternal berpengaruh positif pada kecenderungan kecurangan akuntansi. Hal ini menunjukkan bahwa semakin tinggi locus of control eksternal seseorang menyebabkan semakin tinggi tindakan kecenderungan kecurangan akuntansi. Seseorang dengan locus of control eksternal meyakini kejadian dalam hidupnya dipengaruhi oleh takdir dan keberuntungan serta kekuasaan di luar dirinya, sehingga kejadian - kejadian yang terjadi pada dirinya adalah diluar pengendaliannya.

Hasil penelitian ini menunjukan bahwa Pengendalian Internal, dan Komptensi berpengaruh negatif Sedangkan Locus of Control berpengaruh positif pada kecenderungan kecurangan akuntansi berdasarkan hasil penelitian tersebut sejalan dengan teori atribusi dan Fraud Triangle Teory yang menjelaskan bahwa kecurangan akuntansi terjadi karena perilaku atau karakteristik yang dimiliki oleh seseorang.

\section{SIMPULAN}

Berdasarkan hasil analisis data dan pembahasan yang telah diuraikan sebelumnya, maka dapat ditarik kesimpulan bahwa pengendalian internal berpengaruh negatif pada kecenderungan kecurangan akuntansi. Semakin baik pengendalian internal dalam Dinas Pendapatan Daerah Kota Denpasar menyebabkan tingkat terjadinya kecenderungan kecurangan akuntansi menurun. Hal ini dikarenakan adanya pengawasan dan evaluasi atas aktivitas-aktivitas operasional dalam instansi. Kompetensi berpengaruh negatif pada kecenderungan kecurangan akuntansi. Semakin tinggi tingkat kompetensi seseorang menyebabkan semakin rendah 
I Gede Beni Wirakusuma dan Putu Ery Setiawan. Pengaruh...

tindakan kecenderungan kecurangan akuntansi yang dilakukan. Hal ini dikarenakan jika seseorang memiliki pengalaman yang baik di bidangnya maka hal tersebut akan menjauhkan seseorang untuk melakukan tindakan kecurangan akuntansi. Dan locus of control eksternal berpengaruh positif pada kecenderungan kecurangan akuntansi. Semakin tinggi tingkat locus of control eksternal seseorang menyebabkan semakin tinggi tindakan kecenderungan kecurangan akuntansi yang dilakukan.

Saran yang dapat diberikan berdasarkan simpulan yang telah disampaikan adalah diisarankan untuk Dinas Pendapatan Daerah Kota Denpasar dapat meningkatkan pengendalian internal dan selalu dapat menjaga standar yang tinggi untuk pengendalian internal tersebut dan juga meningkatkan kompetensi karyawannya untuk dapat meminimalisir kecurangan akuntansi yang terjadi di lembaga. Disarankan Dinas Pendapatan Daerah Kota Denpasar perlu memperhatikan masing - masing pegawai terutama locus of Control yang bersifat eksternal dengan cara memberikan kebebasan kepada pegawainya untuk bebas mengeluarkan pendapat dan terbuka antar pegawainya. Pada Penelitian ini ada Beberapa variabel yang berpengaruh yang tidak diteliti oleh peneliti seperti : tingkat pendidikan, independensi, profesionalitas. Peneliti tidak menggunakan variabel tersebut karena tidak sesuai dengan teori yang peneliti gunakan. Variabel yang digunakan pada penelitian ini relevan dengan teori yang peneliti gunakan. 


\section{REFERENSI}

Abdul Wahid, M. N., \& Zulkarnain, Z. A. (2011). Applying packet generator for secure network environment. Journal of Computer Science.

Adelin, V., \& Fauzihardani, E. (2013). Pengaruh Pengendalian Internal, Ketaatan Aturan Akuntansi, Dan Kecendrungan Kecurangan Terhadap Perilaku Tidak Etis (Studi Empiris pada BUMN di Kota Padang). Fakultas Ekonomi Universitas Negeri Padang.

Albrecht, W. S., Albrecht, C. O., Albrecht, C. C., \& Zimbelman, M. F. (2012). Fraud Examination. South-Western Cengage Learning.

Andrawina, L., \& Kurniawati, A. (2012). Framework for Community of Practice based on SECI method and KM cycle. In International Conference on ICT and Knowledge Engineering (pp. 189-193).

Coram, P., Ferguson, C., \& Moroney, R. (2008). Internal audit, alternative internal audit structures and the level of misappropriation of assets fraud. Accounting and Finance.

Donelson, D. C., Ege, M. S., \& McInnis, J. M. (2017). Internal control weaknesses and financial reporting fraud. Auditing.

Dorminey, J., Flemming, A. S., Kranacher, M.-J., \& Riley, R. A. (2010). Beyond the Fraud Triangle Enhancing Deterrence of Economic Crimes. The CPA Journal.

Hermiyetti, \& Manik, E. N. (2010). The Influence of Good Corporate Governance Mechanism on Earnings Management: Empirical Study in Indonesian Stock Exchange Listed Company for Periods of 2006-2010. Indonesian Capital Market Review, V(1), 2010.

Johnson-Rokosu, S. (2015). Integrating Forensic Accounting Core Competency into the Study of Accounting: Case of Nigeria Tertiary Institutions. Academic Journal of Economic Studies.

Khine, M. S., Saleh, I. M., Sawyer, R. K., Khine, M. S., Saleh, I. M., Sawyer, R. K., ... Saleh, I. M. (2005). The new science of learning. The Cambridge Handbook.

Lee, H. W. (2013). Locus of control, socialization and organizational identification. Actual Problems of Economics.

Norbarani, L. (2012). Pendeteksian Kecurangan Laporan Keuangan Dengan Analisis Fraud Triangle Yang Diadopsi Dalam SAS No.99. Ekonomika Dan Bisnis, (99), 69. 
Pedneault, S., Silverstone, H., Rudewicz, F., \& Sheetz, M. (2012). Forensic Accounting and Fraud Investigation for Non-Experts. Journal of Chemical Information and Modeling.

Popoola, O. M. J., Che-Ahmad, A., \& Samsudin, R. S. (2014). Forensic Accounting and Fraud: Capability and Competence Requirements in Malaysia. Journal of Modern Accounting and Auditing.

Putri, A. A. P. A. (2014). Pengaruh Keefektifan Pengendalian Internal Dan Kepuasan Kerja Terhadap Kecenderungan Kecurangan Akuntansi Pada Dinas Pendapatan Pengelolaan Keuangan Aset Daerah Istimewa Yogyakarta. Nominal: Barometer Riset Akuntansi Dan Manajemen.

Respati. (2011). Pengaruh Locus of Control Terhadap Hubungan Sikap Manajer, Norma-Norma Subyektif, Kendali Perilaku Persepsian, Dan Intensi Manajer Dalam Melakukan Kecurangan Penyajian Laporan Keuangan. Jurnal Akuntansi Dan Keuangan Indonesia, 8(2), 123-140.

Robbins, S. P., \& Judge, T. (2009). Comportamiento Organizacional 13a edicón. Comportamiento Organizacional.

Rubin, A. M. (2009). Locus of control. In Communication Research Measures II: A Sourcebook.

Sawyer, M. (2005). The private finance initiative: the uk experience. Research in Transportation Economics.

Schuchter, A., \& Levi, M. (2016). The Fraud Triangle revisited. Security Journal.

Shintadevi, P. F. (2015). Pengaruh Keefektifan Pengendalian Internal, Ketaatan Aturan Akuntansi dan Kesesuaian Kompensasi terhadap Kecenderungan Kecurangan Akuntansi dan Perilaku Tidak Etis sebagai Variabel Intervening. Jurnal Nominal.

Singleton, T. W., \& Singleton, A. J. (2013). Fraud Auditing and Forensic Accounting. Journal of Chemical Information and Modeling.

Sugiyono. (2011). metodologi penelitian kuantitatif kualitatif dan R \& D. In metodologi penelitian kuantitatif kualitatif dan $R \& D$.

Sugiyono. (2014). Metode penelitian. Metode Penelitian.

Tuanakotta, T. M. (2010). Akuntansi Forensik \& Audit Investigatif. In Edisi 2.

Yendrawati, R. (2013). Pengaruh Sistem Pengendalian Intern dan Kapasitas 
ISSN: 2302-8556

E-Jurnal Akuntansi Universitas Udayana

Vol.26.2.Februari (2019): 1545-1569

Sumber Daya Manusia Terhadap Kualitas Informasi Laporan Keuangan dengan Faktor Eksternal sebagai Variabel Moderating. Jurnal Akuntansi Dan Auditing.

Zainal, R. (2013). Pengaruh Efektivitas Pengendalian Intern, asimetri informasi Dan kesesuaian kompensasi Terhadap Kecenderungan Kecurangan Akuntansi (Fraud). Universitas Negeri Padang. 